\title{
ОСОБЛИВОСТІ ВІЛЬНОРАДИКАЛЬНОГО ОКИСНЕННЯ ПРИ ЕКСПЕРИМЕНТАЛЬНОМУ СИНДРОМІ ТРИВАЛОГО СТИСНЕННЯ
}

Вступ. Особливий інтерес дослідників до вивчення особливостей вільнорадикального окиснення при синдромі тривалого стиснення (СТC) пов'язаний з тим, що в генезисі порушення проникності капілярів і набряку в ході розвитку процесу одним із найважливіших механізмів є посилення генерації вільних радикалів.

Мета дослідження - вивчити в динаміці показники вільнорадикального окиснення у крові та печінці щурів на моделі ендотоксикозу, що фрормується за умов синдрому тривалого стиснення.

Методи дослідження. Досліди проведено на 40 безпородних статевозрілих білих щурах-самцях. Експериментальною моделлю слугував патологічний процес, що розвивався у тварин внаслідок стиснення м'яких тканин лівої тазової кінцівки протягом 4 год у спеціальному пристрої. Площа стискальної поверхні становила $4 \mathrm{~cm}^{2}$, а сила компресії - 4,25 кг/см². При цьому цілісність великих судин і кісткових структур нижньої кінцівки зберігалась. Таким чином, у тварин моделювався синдром тривалого стиснення середнього ступеня. У сироватці крові й печінці визначали вміст гідропероксидів ліпідів (ГПЛ), концентрацію ТБК-активних продуктів (ТБК-АП). Рівень продукування активних фрорм оксигену лейкоцитами крові визначали цитофрлуориметрично.

Результати й обговорення. Результати досліджень вказують на активацію процесів вільнорадикального окиснення як у сироватці крові, так і в печінці щурів у динаміці розвитку СТС. Встановлено достовірне збільшення продукування активних фрорм оксигену лейкоцитами крові тварин у всі доби спостереження, вірогідні зміни показників первинної і вторинної пероксидації ліпідів. При порівнюванні змін концентрації первинних продуктів пероксидного окиснення ліпідів у сироватці крові й супернатанті гомогенату печінки щурів з експериментальним СТС виявлено односпрямовані зміни концентрації ГПЛ у досліджуваних біологічних рідинах з їх переважанням у печінці на 3-14 доби. Зіставлення концентрації ТБК-АП у крові й печінці тварин у динаміці розвитку СТС свідчило також про односпрямоване підвищення досліджуваного показника на 3-7 доби з наступним зниженням на 14-ту добу. Слід зауважити, що на 3-тю добу концентрація ТБК-АП переважала в гомогенаті печінки, тоді як на 14-ту добу рівень даного показника був на 16,9 \% меншим у печінці відносно крові.

Висновок. При експериментальному синдромі тривалого стиснення активація процесів вільнорадикального окиснення характеризується зростанням продукування активних фрорм оксигену лейкоцитами крові щурів у всі доби спостереження, а також достовірними змінами показників первинної і вторинної пероксидації ліпідів у крові та гомогенаті печінки порівняно з контрольною групою.

КЛЮЧОВІ СЛОВА: синдром тривалого стиснення; вільнорадикальне окиснення; кров; печінка.

ВСТУП. Збільшення числа надзвичайних ситуацій супроводжується частими травмами опорно-рухового апарату й стисненням м'яких тканин [1]. Синдром тривалого стиснення (СТС) становить 15-24 \% у структурі травматичних уражень та характеризується тяжким перебігом, розвитком синдромів системної запальної відповіді й дисемінованого внутрішньосудинного згортання, що призводить до втягнення великої кількості органів у патологічний процес та до поліорганної недостатності [2, 3]. Через високу летальність при тяжких формах синдрому тривалого стиснення (приблизно 85-90 \%) важли(с) Т. П. Пилипчук, І. Я. Криницька, М. І. Марущак, 2018 вим є вивчення механізмів, що перебігають у динаміці даного патологічного синдрому [4].

Особливий інтерес дослідників до вивчення особливостей вільнорадикального окиснення при СТС пов'язаний з тим, що в генезисі порушення проникності капілярів і набряку в ході розвитку процесу одним із найважливіших механізмів є посилення генерації вільних радикалів [5].

Мета дослідження - вивчити в динаміці показники вільнорадикального окиснення у крові та печінці щурів на моделі ендотоксикозу, що фрормується за умов синдрому тривалого стиснення. 
МЕТОДИ ДОСЛІДЖЕННЯ. Досліди проведено на 40 безпородних статевозрілих білих щурах-самцях масою 180-200 г, яких поділили на 5 груп: контрольну $(\mathrm{n}=8)$, експериментальні (1-ша, 3-тя, 7-ма і 14-та доби спостереження) по 8 тварин на кожен термін спостереження.

Вибрані терміни спостереження відповідали загальноприйнятим періодам розвитку синдрому тривалого стиснення: від 1 до 3 діб - ранній період; від 3 до 7 діб - проміжний період; від 7 до 21 доби - пізній (відновний) період [6].

Досліди проводили під наркозом шляхом внутрішньочеревного введення кетаміну гідрохлориду (з розрахунку 100 мг/кг маси тіла). Експериментальною моделлю слугував патологічний процес, що розвивався у тварин внаслідок стиснення м'яких тканин лівої тазової кінцівки протягом 4 год у спеціальному пристрої, сконструйованому на кафедрі функціональної та лабораторної діагностики Тернопільського державного медичного університету імені І. Я. Горбачевського.

Площа стискальної поверхні становила

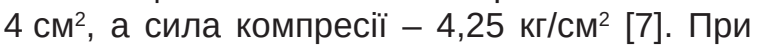
цьому цілісність великих судин і кісткових структур нижньої кінцівки зберігалась. Таким чином, у тварин моделювався синдром тривалого стиснення середнього ступеня.

Для дослідження використовували сироватку крові, гемолізат еритроцитів та гомогенат печінки. Усі маніпуляції з експериментальними тваринами проводили з дотриманням правил відповідно до Європейської конвенції про захист хребетних тварин, що використовуються для дослідних та інших наукових цілей [8].

У сироватці крові й печінці визначали: вміст гідропероксидів ліпідів (ГПЛ) - за методом В. В. Мирончика (1984) [9], концентрацію ТБК-активних продуктів (ТБК-АП) - за методом Е. Н. Коробейникової (1989) [10]. Для визначення рівня продукування активних форм оксигену (АФО) лейкоцитами крові використовували барвник із заблокованою фрлуоресценцією - дихлорфрлуоресцеїну діацетат (“SigmaAldrich”, США) [11].

Статистичну обробку цифрових даних здійснювали за допомогою програмного забезпечення Excel ("Microsoft", США) і STATISTICA 6.0 ("Statsoft", США) з використанням непараметричних методів оцінки одержаних даних. Розраховували медіану і квартилі розподілу $\mathrm{Me}\left[\mathrm{Q}_{25}-\mathrm{Q}_{75}\right]$. Достовірність різниці значень між незалежними кількісними величинами встановлювали за допомогою U-критерію Манна - Уїтні.

РЕЗУЛЬТАТИ Й ОБГОВОРЕННЯ. РезУЛЬТаТИ досліджень вказують на активацію процесів вільнорадикального окиснення як у сироватці крові, так і в печінці щурів у динаміці розвитку СТС. Встановлено достовірне збільшення продукування АФО лейкоцитами крові тварин у всі доби спостереження, зокрема, на 1-шу добу - в 2,8 раза, на 3-тю-у 3,4 раза, на 7-му-в 3,3 раза, на 14-ту - в 3,0 рази відносно контрольної групи щурів (рис. 1). Варто відмітити, що на 3-тю добу спостереження генерація АФО лейкоцитами крові була достовірно більшою на 22,6 \% проти даних на 1-шу добу $(p<0,01)$ та залишалася практично незмінною до завершення експериментів.

Встановлено вірогідні зміни показників первинної і вторинної пероксидації ліпідів. Так, у сироватці крові концентрація ГПЛ на 1-шу добу спостереження достовірно зросла на 34,3 \%, на 3-тю - на 74,6 \%, на 7-му - на 67,2 \%, на 14-ту на 35,8 \% відносно тварин контрольної групи (табл.). Слід відмітити, що на 3-тю добу спостереження вона була вірогідно більшою на 30,0 \% проти даних на 1-шу добу $(p<0,01)$ та залишалася практично незмінною до 7-ї доби. На 14-тю добу показник ГПЛ достовірно зменшився на 18,8 \% відносно даних попередньої доби спостереження.

У гомогенаті печінки концентрація ГПЛ на 1-шу добу спостереження достовірно зросла на 41,8\%, на 3-тю-на 110,1\%, на 7-му - на 102,9\%, на 14-ту - на 60,1 \% відносно тварин контрольної групи (табл.). Слід відзначити, що на 3-тю добу спостереження вона була вірогідно більшою на 48,1 \% проти даних на 1-шу добу $(p<0,01)$ та залишалася практично незмінною до 7-ї доби. На 14-тю добу показник ГПЛ достовірно зменшився на 21,1 \% відносно даних попередньої доби спостереження.

У сироватці крові концентрація ТБК-АП на 1-шу добу спостереження вірогідно не відрізнялася від показника контрольної групи, на 3-тю достовірно зросла на 40,3 \%, на 7-му - на 58,5 \%, на 14-ту - на 59,6 \% відносно тварин контрольної групи. Слід відмітити, що на 3-тю добу спо-

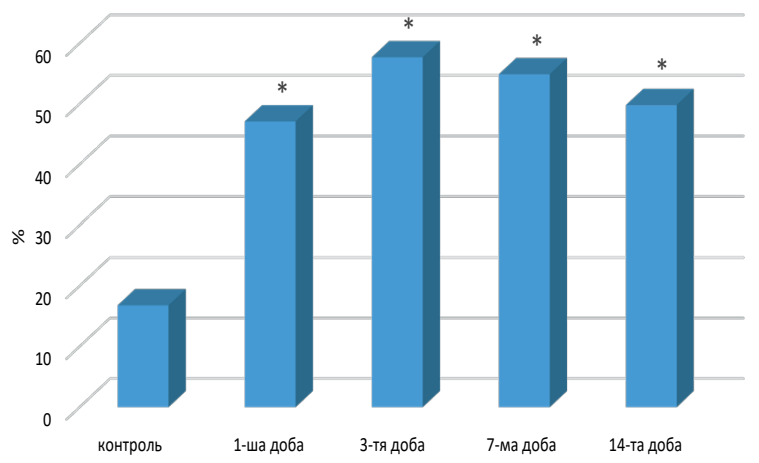

Рис. 1. Динаміка змін генерації активних фрорм оксигену лейкоцитами крові щурів у динаміці розвитку синдрому тривалого стиснення (* - зміни достовірні відносно показників тварин контрольної групи). 
Таблиця - Зміни показників пероксидного окиснення ліпідів у крові та печінці щурів у динаміці розвитку синдрому тривалого стиснення (Me $\left.\left[\mathrm{Q}_{25}-\mathrm{Q}_{75}\right]\right)$

\begin{tabular}{|c|c|c|c|c|c|}
\hline \multirow{2}{*}{ Показник } & \multicolumn{5}{|c|}{ Група тварин } \\
\hline & контрольна $(\mathrm{n}=8)$ & 1-ша доба $(n=8)$ & 3-тя доба (n=8) & 7-ма доба $(n=8)$ & 14-та доба (n=8) \\
\hline \multicolumn{6}{|c|}{ Сироватка крові } \\
\hline $\begin{array}{l}\text { ГПЛ, } \\
\Delta Д 480 / м л\end{array}$ & $\begin{array}{c}0,67 \\
{[0,56 ; 0,76]}\end{array}$ & $\begin{array}{c}0,90 \\
{[0,87 ; 0,95]} \\
p_{1}<0,05\end{array}$ & $\begin{array}{c}1,17 \\
{[1,10 ; 1,22]} \\
p_{1}<0,05 \\
p_{2}<0,05\end{array}$ & $\begin{array}{c}1,12 \\
{[0,98 ; 1,23]} \\
p_{1}<0,05\end{array}$ & $\begin{array}{c}0,91 \\
{[0,86 ; 0,96]} \\
p_{1}<0,05 \\
p_{4}<0,05\end{array}$ \\
\hline $\begin{array}{l}\text { ТБК-АП, } \\
\text { нмоль/мл }\end{array}$ & $\begin{array}{c}5,44 \\
{[5,21 ; 5,65]}\end{array}$ & $\begin{array}{c}5,71 \\
{[5,43 ; 6,00]}\end{array}$ & $\begin{array}{c}7,63 \\
{[7,33 ; 7,94]} \\
p_{1}<0,05 \\
p_{2}<0,05\end{array}$ & $\begin{array}{c}8,62 \\
{[8,24 ; 8,99]} \\
\mathrm{p}_{1}<0,05 \\
\mathrm{p}_{3}<0,05\end{array}$ & $\begin{array}{c}8,68 \\
{[8,44 ; 8,93]} \\
p_{1}<0,05\end{array}$ \\
\hline \multicolumn{6}{|c|}{ Гомогенат печінки } \\
\hline $\begin{array}{l}\text { ГПЛ, } \\
\triangle Д 480 / г ~\end{array}$ & $\begin{array}{c}2,08 \\
{[1,80 ; 2,25]}\end{array}$ & $\begin{array}{c}2,95 \\
{[2,80 ; 3,06]} \\
p_{1}<0,05\end{array}$ & $\begin{array}{c}4,37 \\
{[3,86 ; 4,66]} \\
p_{1}<0,05 \\
p_{2}<0,05\end{array}$ & $\begin{array}{c}4,22 \\
{[3,85 ; 4,47]} \\
p_{1}<0,05\end{array}$ & $\begin{array}{c}3,33 \\
{[2,95 ; 3,64]} \\
p_{1}<0,05 \\
p_{4}<0,05\end{array}$ \\
\hline $\begin{array}{l}\text { ТБК-АП, } \\
\text { нмоль/г }\end{array}$ & $\begin{array}{c}7,75 \\
{[7,39 ; 8,43]}\end{array}$ & $\begin{array}{c}9,69 \\
{[9,42 ; 9,98]} \\
p_{1}<0,05\end{array}$ & $\begin{array}{c}12,23 \\
{[11,63 ; 12,75]} \\
p_{1}<0,05 \\
p_{2}<0,05\end{array}$ & $\begin{array}{c}12,22 \\
{[11,80 ; 12,76]} \\
p_{1}<0,05\end{array}$ & $\begin{array}{c}11,06 \\
{[10,64 ; 11,40]} \\
p_{1}<0,05 \\
p_{4}<0,05\end{array}$ \\
\hline
\end{tabular}

Примітки:

1. $p_{1}$ - достовірність змін відносно показників тварин контрольної групи.

2. $\mathrm{p}_{2}$ - достовірність змін між тваринами на 1-шу добу спостереження та щурами на 3-тю добу.

3. $p_{3}$ - достовірність змін між тваринами на 3-тю добу спостереження та щурами на 7-му добу.

4. $\mathrm{p}_{4}$ - достовірність змін між тваринами на 7-му добу спостереження та щурами на 14-ту добу.

стереження вона була вірогідно більшою на 33,6 \% проти даних на 1-шу добу. На 7-му добу цей показник достовірно перевищував концентрацію ТБК-АП на 3-тю добу на 13,0 \%. На 14-ту добу концентрація ТБК-АП залишалася практично незмінною.

У гомогенаті печінки концентрація ТБК-АП на 1-шу добу спостереження достовірно зросла на 25,0 \%, на 3-тю - на 57,8 \%, на 7-му - на $57,7 \%$, на 14-ту - на 42,7 \% відносно тварин контрольної групи. Слід відзначити, що на 3-тю добу спостереження вона була вірогідно більшою на 26,2 \% проти даних на 1-шу добу $(p<0,01)$ та залишалася практично незмінною до 7-ї доби. На 14-ту добу показник ТБК-АП достовірно зменшився на 9,5 \% відносно даних попередньої доби спостереження.
При порівнюванні змін концентрації первинних продуктів пероксидного окиснення ліпідів у сироватці крові й супернатанті гомогенату печінки щурів з експериментальним СТС виявлено односпрямовані зміни концентрації ГПЛ у досліджуваних біологічних рідинах з їх переважанням у печінці на 3-тю (на 35,4 \%), 7-му (на 35,8 \%) і 14-ту (на 25,1 \%) доби (рис. 2). Зіставлення концентрації ТБК-АП у крові й печінці тварин у динаміці розвитку СТС свідчило також про односпрямоване підвищення досліджуваного показника на 3-7 доби з наступним зниженням на 14-ту добу. Слід зауважити, що на 3-тю добу концентрація ТБК-АП переважала в гомогенаті печінки (на 17,7 \%), тоді як на 14-ту добу рівень даного показника був на 16,9 \% меншим у печінці відносно крові (рис. 3).

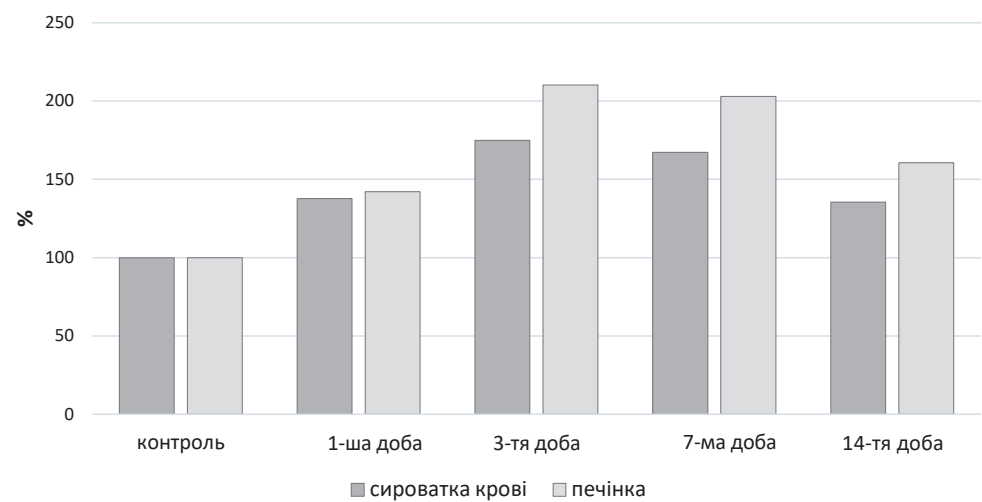

Рис. 2. Зіставлення концентрації гідропероксидів ліпідів у крові й печінці щурів у динаміці розвитку синдрому тривалого стиснення. 


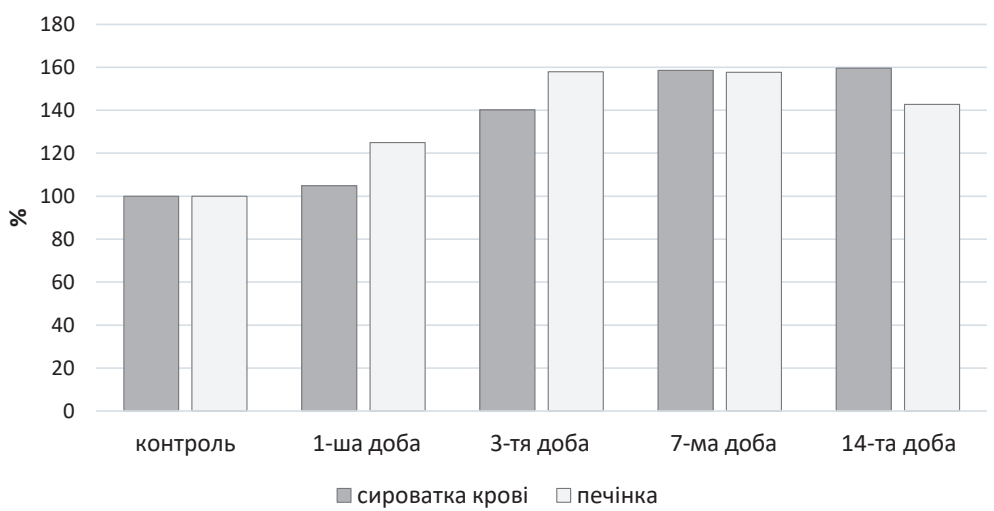

Рис. 3. Зіставлення концентрації ТБК-активних продуктів у крові й печінці щурів у динаміці розвитку синдрому тривалого стиснення.

Згідно з літературними джерелами, пусковим механізмом у розвитку патологічних змін при СТС $\epsilon$ надходження в системний кровотік продуктів міолізу і продуктів порушеного обміну зі зруйнованих та ішемізованих м'язів після декомпресії $[12,13]$. Внаслідок механічного руйнування тканин у поєднанні з артеріальною недостатністю і венозним застоєм запускаються процеси пероксидного окиснення ліпідів і протеїнів, утворюється велика кількість токсичних продуктів метаболізму клітин. Отримані дані підтверджують зростання процесів вільнорадикального окиснення в печінці й крові тварин з експериментальним СТС, які досягали максимуму на 7-му добу.

ВИСНОВКИ. 1. При експериментальному синдромі тривалого стиснення активація процесів вільнорадикального окиснення характеризу- ється зростанням продукування АФО лейкоцитами крові щурів у всі доби спостереження, а також достовірними змінами показників первинної і вторинної пероксидації ліпідів у крові та гомогенаті печінки порівняно з контрольною групою $(p \leq 0,05)$.

2. За умови синдрому тривалого стиснення в сироватці крові й супернатанті гомогенату печінки щурів виявлено односпрямовані зміни концентрації гідропероксидів ліпідів у досліджуваних біологічних рідинах з їх переважанням у печінці на 3-тю (на 35,4 \%), 7-му (на 35,8 \%) і 14-ту (на 25,1 \%) доби ( $p \leq 0,01)$, тоді як концентрація активних продуктів тіобарбітурової кислоти на 3-тю добу переважала в гомогенаті печінки (на 17,7 \%), а на 14-ту добу рівень даного показника був на 16,9 \% меншим у печінці відносно крові $(p \leq 0,05)$.

\section{СПИСОК ЛІТЕРАТУРИ}

1. Зарубина И. В. Значение индивидуальной устойчивости к гипоксии для течения тяжелой компрессионной травмы / И. В. Зарубина, И. А. Юнусов, П. Д. Шабанов // Патологическая фризиология и экспериментальная терапия. - 2010. - № 3. - С. 24-29.

2. Содержание бактериального липополисахарида в динамике декомпрессионного периода экспериментального синдрома длительного сдавления / Е. Н. Самсонова, А. В. Ефремов, Д. Д. Цырендоржиев, В. Ю. Радустов // Дальневосточный мед. журн. 2005. - № 1. - 15-17.

3. Структурные изменения легких и фрункциональное состояние легочных макрофрагов в динамике декомпрессионного периода экспериментального синдрома длительного сдавления / В. Ю. Радустов, Д. Д. Цырендоржиев, Х. Б. Цыренова [и др.] // Бюлл. СО РAMH. - 2011. - 31, № 1. - С. 27-33.
4. Разработка методики моделирования синдрома длительного сдавления / А. П. Трухан, С. А. Жидков, В. Е. Корик [и др.] // Военная медицина. - 2013. № 3. - C. 105-107.

5. Магомедов К. К. Коррекция персртораном структурно-функционального гомеостаза при синдроме длительного сдавливания : авторефр. дисс. на соискание ученой степени канд. биол. наук. / К. К. Магомедов. - Ростов-на-Дону, 2013. - 20 с.

6. Нечаев Э. А. Синдром длительного сдавления : руководство для врачей / Э. А. Нечаев, А. К. Ревской, Г. Г. Савицкий. - М. : Медицина, 1993. - 208 с.

7. Involvement of nitric oxide system in experimental muscle crush injury / I. Rubinstein, Z. Abassi, R. Coleman [et al.] // J. Clin. Invest. - 1998. - 101 (6). - P. 1325-1333.

8. European convention for the protection of vertebrate animals used for experimental and other scientific 
purposes. - Council of Europe. Strasbourg. - 1986. No. 123. -52 p.

9. А. с. 1084681 СССР, МКИ G № 33/48. Способ определения содержания гидроперекисей липидов в биологических тканях / В. В. Мирончик (СССР). № 3468369/2813 ; заявл. 08.07.82 ; опубл. 07.04.84, Бюл. 13.

10. Коробейникова Э. Н. Модификация определения ПОЛ в реакции с тиобарбитуровой кислотой / Э. Н. Коробейникова // Лаб. дело. - 1989. - № 7. C. 8-9.

11. Flow cytometric studies of oxidative product formation by neutrophils: a graded response to membrane stimu- lation / D. A. Bass, J. W. Parce, L. R. Dechatelet [et al.] // J. Immunol. - 1983. - 130 (4). - P. 1910-1917.

12. Современные аспекты патогенеза синдрома длительного сдавления в клинике и эксперименте / К. Я. Шугаева, М. А. Магомедов, К. К. Магомедов, Р. К. Шахбанов // Изв. Дагест. гос. пед. ун-та. Естественные и точные науки. - 2012. - № 2. - С. 96-100.

13. Trukhan A. P. The assessment of efficiency of tourniquet application as a component of the first aid at crush syndrome. Report 1: the changes of biochemical parameters / A. P. Trukhan // Novosti Khirurgii. - 2014. 22 (3). - P. 280-385.

\section{REFERENCES}

1. Zarubina, I.V., Yunusov, I.A., \& Shabanov, P.D. (2010). Znachenie individualnoy ustoychivosti k gipoksii dlya techeniya tyazheloy kompressionnoy travmy [The value of individual resistance to hypoxia for a severe compressive trauma]. Patologicheskaya fiziologiya $i$ eksperimentalnaya terapiya - Pathological Physiology and Experimental Therapy, 3, 24-29 [in Russian].

2. Samsonova, E.N., Efremov, A.V., Tsyrendorzhiev, D.D., Radustov, V.Yu. (2005). Soderzhanie bakterialnogo lipopolisaharida $v$ dinamike dekompressionnogo perioda eksperimentalnogo sindroma dlitelnogo sdavleniya [Content of bacterial lipopolysaccharide in the dynamics of the decompression period of the experimental long-term compression syndrome]. Dalnevostochnyy med. zhurn. - Far Eastern Med. Journ., 1, 15-17 [in Russian].

3. Radustov, V.Yu., Tsyrendorzhiev, D.D., \& Tsyrenova, H.B. (2011). Strukturnye izmeneniya legkih i funktsionalnoe sostoyanie legochnykh makrofagov $v$ dinamike dekompressionnogo perioda eksperimentalnogo sindroma dlitelnogo sdavleniya [Structural changes in the lungs and the functional state of lung macrophages in the dynamics of the decompression period of the experimental syndrome of prolonged compression]. Byulleten SO RAMN - Bulletin of the SB RAMS, 31(1), 27-33 [in Russian].

4. Trukhan, A.P., Zhidkov, S.A., \& Korik, V.E. (2013). Razrabotka metodiki modelirovaniya sindroma dlitelnogo sdavleniya [Development of the technique of simulation of long-term compression syndrome]. Voennaya meditsina - Military Medicine, 3, 105-107 [in Russian].

5. Magomedov, K.K. (2013). Korrektsiya perftoranom strukturno-funktsionalnogo gomeostaza pri sindrome dlitelnogo sdavlivaniya [Correction of perfluorane of structural-functional homeostasis in prolonged squeezing syndrome]. Rostov-on-Don, 2013 [in Russian].
6. Nechaev, E.A., Revsky, A.K., \& Savitsky, G.G. (1993). Sindrom dlitelnogo sdavleniya: Rukovodstvo dlya vrachey [Syndrome of prolonged compression: Manual for doctors]. Moscow: Medicine [in Russian].

7. Rubinstein, I., Abassi, Z., Coleman, R., et al. (1998). Involvement of the nitric oxide system in the experimental muscle crush injury. J. Clin. Invest., 101 (6), 1325-1333.

8. European convention for the protection of vertebrate animals used for experimental and other scientific purposes. (1986). Council of Europe. Strasbourg, 123, 52.

9. Mironchik, V.V. (1984) Sposob opredeleniya gidroperekisey lipidov $v$ biologicheskih tkanyah [A method for determining lipid hydroperoxides in biological tissues]. Certificate of the USSR No. 1084681, MKI G 33/48, No. 3468369/2813, BUL. 13 [in Russian].

10. Korobeynikova, E.N. (1989). Modifikatsiya opredeleniya POL $v$ reaktsii $S$ TBK [Modification of the determination of the LPO in the reaction with TBK]. Lab. Delo - Laboratory Work, 7, 8-9 [in Russian].

11. Bass, D.A., Parce, J.W., \& Dechatelet, L.R. (1983). Flow cytometric studies of oxidative product formation by neutrophils: a graded response to membrane stimulation. J. Immunol., 130 (4), 1910-1917.

12. Shugaeva, K.Ya., Magomedov, M.A., Magomedov, K.K., \& Shakhbanov, R.K. (2012). Sovremennye aspekty patogeneza sindroma dlitelnogo sdavleniya $\mathrm{V}$ klinike i eksperimente [Modern aspects of pathogenesis of long-term compression syndrome in a clinic and an experiment]. Izv. Dagest. gos. ped. un-ta. Estestv. i toch. nauki - News of Dagest State Pedagogical University. Natural Sciences and Exact Science, 2, 96-100 [in Russian].

13. Trukhan, A.P. (2014). The evaluation of the effectiveness of tourniquet application as a component of the first aid in the crush syndrome. Report 1: changes in biochemical parameters. Novosti Khirurgii, (3), 280-385. 


\section{ОСОБЕННОСТИ СВОБОДНОРАДИКАЛЬНОГО ОКИСЛЕНИЯ ПРИ ЭКСПЕРИМЕНТАЛЬНОМ СИНДРОМЕ ДЛИТЕЛЬНОГО СДАВЛИВАНИЯ}

\section{Резюме}

Вступление. Особый интерес исследователей к изучению особенностей свободнорадикального окисления при синдроме длительного сдавливания (СДС) связан с тем, что в генезисе нарушения проницаемости капилляров и отека в ходе развития процесса одним из важнейших механизмов является усиление генерации свободных радикалов.

Цель исследования - изучить в динамике показатели свободнорадикального окисления в крови и печени крыс на модели эндотоксикоза, что фрормируется в условиях синдрома длительного сдавливания.

Методы исследования. Опыты проведены на 40 беспородных половозрелых белых крысах-самцах. Экспериментальной моделью служил патологический процесс, который развивался у животных вследствие сдавливания мягких тканей левой тазовой конечности в течение 4 ч в специальном устройстве. Площадь сжимающей поверхности составляла 4 см² $^{2}$ а сила компрессии - 4,25 кг/см². При этом целостность крупных сосудов и костных структур нижней конечности сохранялась. Таким образом, у животных моделировался синдром длительного сдавливания средней степени. В сыворотке крови и печени определяли содержание гидроперекисей липидов (ГПЛ), концентрацию ТБК-активных продуктов (ТБК-АП). Уровень продуцирования активных фрорм кислорода лейкоцитами крови определяли цитофрлуориметрично.

Результаты и обсуждение. Результаты исследований указывают на активацию процессов свободнорадикального окисления как в сыворотке крови, так и в печени крыс в динамике развития СДС. Установлено достоверное увеличение продуцирования активных фрорм кислорода лейкоцитами крови животных во все периоды наблюдения, вероятные изменения показателей первичного и вторичного перекисного окисления липидов. При сравнивании изменений концентрации первичных продуктов перекисного окисления липидов в сыворотке крови и супернатанте гомогената печени крыс с экспериментальным СДС выявлено однонаправленные изменения концентрации ГПЛ в исследуемых биологических жидкостях с их преобладанием в печени на 3-14 сутки. Сопоставление концентрации ТБК-АП в крови и печени животных в динамике развития СДС свидетельствовало также об однонаправленном повышении исследуемого показателя на 3-7 сутки с последующим снижением на 14-е сутки. Следует отметить, что на 3-и сутки концентрация ТБК-АП преобладала в гомогенате печени, тогда как на 14-е сутки уровень данного показателя был на 16,9 \% меньше в печени относительно крови.

Вывод. При экспериментальном синдроме длительного сдавливания активация процессов свободнорадикального окисления характеризуется возрастанием продуцирования активных фрорм кислорода лейкоцитами крови крыс во все периоды наблюдения, а также достоверными изменениями показателей первичного и вторичного перекисного окисления липидов в крови и гомогенате печени по сравнению с контрольной группой.

КЛЮЧЕВЫЕ СЛОВА: синдром длительного сдавливания; свободнорадикальное окисление; кровь; печень.

\section{THE PECULIARITIES OF FREE RADICAL OXIDATION AT THE EXPERIMENTAL CRUSH-SYNDROME DEVELOPMENT}

\section{Summary}

Introduction. Researchers are particularly interested in studying the features of free radical oxidation in the crush-syndrome because in the genesis of capillary permeability and edema disturbance during the development process, one of the most important mechanisms is to enhance of free radicals generation.

The aim of the study - to investigate in dynamics the indicators of free radical oxidation in the blood and liver of rats on the model of endotoxicosis, which is formed in the conditions of the crush-syndrome. 
Research Methods. Experiments were conducted on 40 adult white male rats. The experimental model was a pathological process that developed in animals as a result of the compression of the soft tissues of the left pelvic limb for 4 hours in a special device. The area of the compressive surface was $4 \mathrm{~cm}^{2}$, and the force of compression was $4.25 \mathrm{~kg} / \mathrm{cm}^{2}$. At the same time, the integrity of large vessels and bone structures of the lower limb was maintained. Thus, a moderate degree of crush-syndrome was simulated. The content of lipid hydroperoxides and the concentration of TBA-active products were determined in serum and liver. The level of production of reactive oxygen species by blood leukocytes was determined cytofluorimetrically.

Results and Discussion. The results of the study indicate the activation of the processes of free radical oxidation in the serum and liver of rats in the development of crush-syndrome. A significant increase in reactive oxygen species production by leukocytes during all periods of observation was established, changes in the indices of primary and secondary peroxidation were established. Comparing changes in the concentration of primary lipid peroxidation products in the serum and the liver homogenate supernatant of rats with experimental crush-syndrome, unidirectional changes in the concentration of lipid hydroperoxides in the studied biological fluids were found with their prevalence in the liver for 3-14 days. Comparison of the concentration of TBA-active products in the blood and liver of rats in the dynamics of the development of crush-syndrome also indicates an unidirectional growth of the studied indicator for 3-7 days with a subsequent decrease on the 14th day. It should be noted that on the 3rd day the concentration of TBA-AP prevailed in the liver homogenate, whereas on the 14th day the level of this indicator was $16.9 \%$ less in the liver, relative to the blood.

Conclusion. In case of experimental crush syndrome activation of free radical oxidation processes is characterized by an increase in reactive oxygen species production by blood leukocytes during all periods of observation, as well as significant changes in the indices of primary and secondary peroxidation in the blood and the liver homogenate compared with the control group.

KEY WORDS: crush-syndrome; free radical oxidation; blood; liver.

Адреса для листування: М. І. Марущак, Тернопільський державний медичний університет імені І. Я. Горбачевського, майдан Волі, 1, Тернопіль, 46001, україна, е-mail: marushchak@tdmu.edu.ua. 